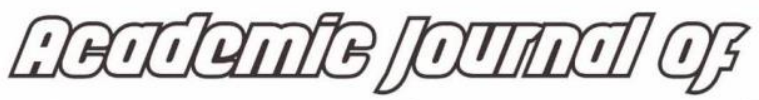

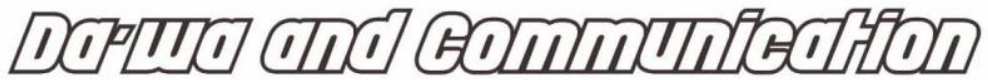

\section{JURNALISME ERA BARU \\ (KONVERGENSI MEDIA RADAR JOGJA DALAM MENGHADAPI PERSAINGAN MEDIA)}

\section{Titik Wahyuningsih}

Abraham Zakky Zulhazmi

IAIN Surakarta

\begin{tabular}{l}
\hline Keywords: \\
Media \\
concergence; Radar \\
Jogja; media \\
competition \\
\hline
\end{tabular}

Alamat korespondensi: titikwah2@gmail.com

\begin{abstract}
Freedom of the press after the 1998 reform had an impact on increasing the number of mass media in Indonesia. Coupled with the presence of the internet as new media, making media competition increasingly complex. Faced with this phenomenon a number of media began to try to unite information technology, communication and content which is referred to as media convergence. This research is a qualitative research. Research data collection is done by observation, interview and documentation. This research concludes that Radar Jogja implements the concept of continuum convergence. Radar Jogja has carried out four stages of continuum convergence namely cross promotion, cloning, coopetition, and content sharing. While the form of Radar Jogja's media convergence implementation in the face of media competition, is identified as follows (1) optimization of new media, Radar Jogja has succeeded in becoming a technologyliterate media as evidenced by its activity on various media platforms. (2) The issue selection strategy, Radar Jogja is able to raise national issues which are then localized according to the conditions on the field. (3) bandling advertising, a strategy to get clients by providing a variety of advertising service choices. (4) coordination, build a solid team and work together to increase loyalty to the company.
\end{abstract}




\begin{tabular}{l} 
Kata kunci: \\
Konvergensi \\
media; Radar \\
Jogja; persaingan \\
media \\
\hline
\end{tabular}

\section{PENDAHULUAN}

Efek reformasi 1998 tidak hanya membuat tatanan negara berubah menjadi lebih demokratis tetapi juga membawa perubahan yang besar terhadap kebijakan kebebasan pers di Indonesia. Adanya perkembangan industri telekomunikasi dan hadirnya internet, memberikan dampak perubahan terhadap bertumbuhnya media online, yang secara bersamaan diikuti oleh menurunnya tingkat baca dan meredupnya media cetak. Berdasarkan survey yang dirilis oleh Nielsen Consumer \& Media View (CMV) kuartal II 2016 yang dilakukan di 11 kota di Indonesia, hanya 9 persen dari generasi muda yang saat ini masih membaca koran, majalah atau tabloid dalam bentuk cetak. Sedangkan sisanya, lebih memilih mengakses informasi melalui televisi atau internet (Romadhoni, 2018).

Hal ini berlaku seiring kebutuhan masyarakat akan informasi juga terus meningkat. Tercatat dalam survey yang dirilis oleh Asosiasi Penyelenggara Jasa Internet Indonesia (APJII) pada tahun 2017, jumlah pengguna internet di Indonesia mencapai 143,26 juta jiwa dari total populasi penduduk Indonesia 262 juta orang. Artinya sebagian besar penduduk di Indonesia tercatat aktif sebagai pengguna internet dengan prosentase 54,68 persen. Hal 
Academic Journal of Da'wa and Communication, Vol. 01, No. 01, April 2020

ini mengalamai peningkatan dibandingkan dengan hasil survey yang dilakukan APJII pada tahun 2016, yang tercatat sebesar 132,7 juta jiwa dari 256,2 juta penduduk. Berkembangnya teknologi internet membuat para kompetitor media massa berlomba-lomba untuk menyajikan berita yang fresh, aktual dan up to date. Merebaknya berita yang bisa diakses melalui internet inilah yang menciptakan budaya baru di masyarakat yaitu budaya digital.

Maraknya media konvensional yang merambah ke dunia digital membuat persaingan antar media semakin meningkat. Ditambah lagi dengan beberapa kalangan yang meramalkan media konvensional salah satunya media cetak bakal tergusur oleh teknologi media yang berbasis digital. Nasib media cetak di Indonesia pun tidak jauh berbeda. Dalam catatan akhir tahun Aliansi Jurnalis Independen, tahun 2015 dikatakan sebagai musim gugur media di Indonesia. Merujuk pada data Nielsen, dari 117 surat kabar yang dilihat, 16 media telah gulung tikar pada 2015 dan majalah dari 170 menyisakan 132 majalah (Permana, 2015).

Hal itu serupa dengan pernyataan Prihartono (2016) mengenai kematian surat kabar di Indonesia pada tahun 2015. Sinar Harapan, Harian Bola dan Jakarta Globe dinyatakan tutup. Mereka tidak mampu bertahan di industri media cetak karena gempuran media online. Seperti yang dilansir CNN Indonesia, Santhika menyatakan bahwa pada awal tahun 2018, Rollling Stone Indonesia menyatakan telah mengakhiri usaha penerbitan majalah musik miliknya. Hal ini diumumkan PT a\&e Media sebagai penerbit majalah Rolling Stone Indonesia dan situs Rolling Stone Indonesia (cnnindonesia.com, 2018). Senjakala media juga dialami oleh salah satu perusahaan media terbesar di Indonesia yaitu Kompas Gramedia Grup. Sebagaimana ditulis tirto.id bahwa perubahan lanskap bisnis yang mengarah pada digital, membuat berbagai media dari KG Grup menghentikan produksi cetak mulai dari Tabloid Bola (Soccer), Majalah Girls, Tabloid Sinyal, Majalah Kawanku, Tabloid Chip, hingga Majalah Hai yang beralih ke plaform online (tirto.id, 2018).

Sedangkan di tingkat lokal, kemunduran bisnis media cetak juga terjadi seperti tutupnya koran Joglosemar. Setelah sepuluh tahun meramaikan ragam informasi kota Solo dan sekitarnya, mulai awal 2018, koran yang dimiliki oleh pengusaha percetakan dan penerbitan S. Haryadi ini resmi ditutup (jawapos.com, 2017). Tumbangnya media cetak juga meninmpa Harian Bernas yang terbit di Yogyakarta. Media tiga zaman yang didirikan Menteri Penerangan pertama RI Mr Soemanang ini resmi tak beroperasi per tanggal 1 Maret 2018. Manajer Sirkulasi Bernas, Tedy Kartyadi menerangkan, kematian tersebut lantaran hantaman internet, sehingga memaksa Bernas bertransformasi ke format digital (alinea.id, 2018). 
Academic Journal of Da'wa and Communication, Vol. 01, No. 01, April 2020

Keberadaan internet dengan tingkat penetrasi yang cukup tinggi menjadi indikasi bahwa masyarakat semakin gemar mengakses berbagai konten melalui media digital (Nielsen, 2017). Menurunnya jumlah pembaca media cetak juga mengakibatkan penurunan jumlah media dan oplahnya. Seperti yang dirilis secara reguler oleh Serikat Penerbit Pers (SPS) dalam Laporan tahunan AJI tahun 2018 adalah salah satu indikasi kuat terkait penururnan jumlah media dan oplah di Indonesia. Menurut pendataan SPS, penurunan jumah media ini terasa sejak tahun 2015 meski penurunan sudah mulai terjadi sejak tahun 2012 dalam jumlah kecil (Manan, 2018).

Penurunan jumlah media itu juga berdampak pada oplahnya. Berdasarkan data yang dihimpun oleh SPS dalam kurun waktu 2011-2017 secara konstan, menunjukkan penurunan oplah berbagai media cetak dari kisaran 25 juta eksemplar menjadi 17 juta eksemplar. Penurunan jumlah oplah ini diikuti dengan penurunan jumlah belanja iklan pada setiap media (Manan, 2018).

Oleh karena itu, budaya digital mau tidak mau membuat para kompetitor media massa berlomba-lomba berinovasi baik dalam bidang konten maupun teknologi untuk menyambut dan bersaing dengan para perusahaan berbasis online lainnya. Hal ini dilakukan untuk memenuhi kebutuhan generasi milenial akan informasi yang cepat dan akurat yang tidak bisa dipisahkan dengan gawai. Selain itu agar eksistensi dari media tersebut tetap terjaga di era yang serba canggih seperti saat ini.

Menurut Jan Van Djik dalam Nasrullah (2014) munculnya media baru juga ditandai dengan konvergensi media. Secara struktural, konvergensi media berati integrasi dari tiga aspek, yakni telekomunikasi, data komunikasi, dan komunikasi massa dalam satu medium. Willis dan Willis dalam Bawapratama (2010) menyatakan bahwa salah satu alasan utama konvergensi media menjadi sebuah jawaban atas upaya eksistensi media meskipun biaya yang dikeluarkan sangatlah besar ialah bahwa pengaplikasian teknologi baru dalam kehidupan bermedia mampu mengurangi pengeluaran media dalam jangka panjang.

Ithiel de Sola Pool melihat konvergensi sebagai sebuah proses kaburnya garis antar media dan menngambarkan kekuatan perubahan dalam industri media. Perangkat fisik tunggal seperti kabel dan gelombang udara, yang pada masa lalu dalam bentuk terpisah, kini dapat diakomodasikan oleh satu medium seperti penyiaran, pers, dan komunikasi lewat telepon (Prihartono, 2016).

Konsep konvergensi media juga diperjelas kembali oleh Henry Jenkis yang menyebut pengertian konvergensi media adalah “...the flow of content across multiple media platforms, the cooperation between multiple media industries and the migratori behaviour of media 
audiences..." (Jenkins, 2006) definisi ini menyatakan bahwa konvergensi media adalah aliran konten di berbagai platform media, kerjasama antara beberapa media industri dan perilaku bermigrasi dari khalayak media. Fenomena konvergensi media dipicu oleh lahirnya media baru dan teknologi digital, di mana saat ini memungkinkan untuk mengakses konten di beberapa platform media.

Teori konvergensi media juga disampaikan oleh Tery Flew dalam bukunya An Intoduction to New Media, yang menyatakan konvergensi media merupakan hasil dari irisan tiga unsur new media yaitu jaringan komunikasi (communication), teknologi informasi (computing), dan konten media (content). Konvergensi media mengusung pada konsep penyatuan berbagai layanan informasi dalam satu piranti informasi membuat satu gebrakan digitalisasi yang tidak bisa dibendung lagi arus informasinya. Konvergensi menyebabkan perubahan radikal dalam penanganan, penyediaan, distribusi dan pemrosesan seluruh bentuk informasi baik visual, audio, data dan sebagainya. (Preston dalam Prihartono, 2016).

Berdasarkan paparan yang disampaikan oleh beberapa tokoh di atas, penulis menarik benang merah bahwa konvergensi media adalah fenomena bergabungnya berbagai media yang sebelumnya dianggap berbeda yang meliputi media cetak maupun media elektronik (misalnya televisi, radio, surat kabar, dan komputer) dan new media menjadi satu ke dalam sebuah media tunggal, atau dengan kata lain penyatuan antara teknologi informasi, komunikasi dan konten. Hal ini sebagai respon dari perkembangan zaman, yang didukung dengan perubahan ekonomi, politik dan sosial.

Terkait dengan proses konvergensi konten yang dilakukan, Dailey, Demo, dan Spillman (2005) mendefinisikan lima tahap konvergensi media berdasarkan tingkat partisipasinya yang lebih dikenal dengan sebutan convergence continuum (konvergensi kontinum). Nastiti (2012) menyatakan bahwa model ini banyak digunakan khususnya terkait dengan prosess konvergensi pemberitaan yang dilakukan dalam organisasi ruang berita atau newsroom. Konvergensi kontinum ini merupakan model yang berfungsi sebagai instrumen untuk mendefinisikan dan mengevaluasi tahapan proses konvergensi yang terjadi dalam suatu ruang berita dan bukan untuk menilai keberhasilan suatu ruang berita (Dailey, 2005). Konvergensi kontinum memiliki lima tahap, yaitu:

Cross-promotion, adalah sebuah proses dari penggunaan kata-kata atau elemen gambar untuk mempromosikan atau mengenalkan konten media yang diproduksi untuk dimunculkan ke platform lain. Hal tersebut biasanya dilakukan dengan mempublikasikan secara visual maupun dengan menampilkan logo secara teratur. Selain itu, bentuk dari cross promotion ini bisa dilakukan dengan mengenalkan konten antar platform secara verbal, dan 
Academic Journal of Da'wa and Communication, Vol. 01, No. 01, April 2020

mengadakan pertemuan untuk mendiskusikan konten yang akan dipromosikan tiap platform.

Cloning, yaitu ketika konten media di muat ulang di platform lain (melalui proses editing atau tanpa editing). Artinya satu media dapat menampilkan konten berita dari ruang berita media lain dengan atau tanpa perubahan.

Coopetition merupakan tahap ketika entitas media yang terkonvergensi saling bekerjasama dan berkompetisi disaat yang bersamaan atau kolaborasi. Tahap koopetisi ditandai dengan aktivitas yang mencerminkan bahwa para anggota dari tiap platform tetap berkompetisi dengan platform lainnya. Pada tahap ini, kedua anggota staf harus menjalankan sifat kooperatif (kerjasama) dan kompetitif (daya saing) secara bersamaan. Artinya meski kedua platform berada dalam satu media, masing-masing anggota tersebut harus mampu menerapkan sikap kooperatif dan kompetitif.

Content sharing, pada tahap ini biasanya ditandai dengan adanya pertemuan secara rutin untuk bertukar ide dan tema oleh masing-masing anggota dan mendistribusikannya ke tiap platform. Memberikan feedback satu sama lain mengenai bagaimana membuat cerita yang bagus, merencanakan proyek khusus atau investigasi bersama, membagi biaya untuk proyek khusus atau investigasi yang mungkin memerlukannya.

Full Convergence, yaitu tahapan konvergensi di mana masing-masing platform telah memiliki editor atau manajer untuk mengelola pembagian proses perencanaan berita (story planning). Memperbolehkan manajer bersama untuk menentukan bagaimana kekuatan masing-masing media yang digunakan untuk memberikan cerita yang paling bermakna bagi penonton, dan membentuk tim yang terdiri dari anggota tiap outlet untuk melipt berita dan mengolahnya. Dalam tahap full convergence, media yang bekerja sama menghasilkan konten dan topik secara kolaboratif dengan memanfaatkan kekuatan platform media masingmasing.

Berkaca dari adanya ramalan media konvensional yang akan gulung tikar serta ancaman kematian media karena tidak memanfaatkan teknologi informasi, sejumlah media nasional dan lokal di Indonesia mulai menerapkan konsep konvergensi. Bertolak dari berbagai permasalahan di atas, penulis tertarik untuk meneliti bagaimana implementasi konvergensi Radar Jogja sebagai perusahaan media agar proses transformasi konvergensi media berjalan sesuai dengan target.

\section{METODE PENELITIAN}


Penelitian ini adalah penelitian deskriptif kualitatif. Data yang dikumpulkan adalah berupa kata-kata, gambar, dan bukanlah angka-angka. Hal itu disebabkan oleh adanya penerapan metode kualitatif. Selain itu, semua yang dikumpulkan berkemungkinan menjadi kunci terhadap apa yang diteliti (Moleong, 2007: 11).

Adapun yang menjadi subjek peneiltian ini adalah Amin Surachmad selaku Dewan Redaksi Radar Jogja. Peneliti menilai bahwa dewan redaksi memiliki peran utama mengenai kebijakan berkaitan dengan konvergensi media. Selanjutnya, peneliti menetapkan Pemimpin Redaksi yakni Yogi Isti Pujiaji dan Reren Indranila selaku Online Manager untuk menjadi informan selanjutnya guna mengetahui bagaimana strategi yang digunakan dalam menghadapi persaingan media massa.

\section{HASIL DAN PEMBAHASAN}

\section{Model Konvergensi Media Radar Jogja}

Sejak berdiri pada tahun 2000, Radar Jogja merupakan media pers berbasis cetak. Meski demikian, Radar Jogja tercatat telah memiliki website dan akun media sosial, ini artinya Radar Jogja semenjak awal kemunculannya sudah melakukan konvergensi media. Namun dalam pengelolaannya masih tergolong sangat kurang, hingga pada awal tahun 2010 muncul berita yang mengabarkan tumbangnya sejumlah media cetak karena gempuran media online. Menyikapi hal tersebut, Radar Jogja mulai melakukan riset dengan mengadakan survei ke beberapa kampung dan instansi-instansi secara sampling. Berdasarkan data yang diperoleh, diketahui bahwa mayoritas masyarakat lebih condong mengakses informasi secara online. Sebagaimana yang disampaikan oleh Dewan Redaksi Radar Jogja.

"Karena perkembangan zaman dan teknologi. Dulu kita nggak peduli dengan media online, tapi sekitar tahun 2010 setelah ada wacana media cetak akan mati nah baru kita berpikir pentingnya menerapkan konvergensi media itu." (Amin Surachmad, Dewan Redaksi, wawancara di kantor Radar Jogja, 6 Agustus 2019).

Berdasarkan keterangan tersebut, perkembangan zaman dan teknologi berpengaruh terhadap jalannya industri media. Mau tidak mau media harus mengimbangi laju perkembangan jaman dan teknologi. Oleh karena itu, Radar Jogja mulai aktif untuk membangun kembali platform online nya baik dari website, Youtube dan media sosial. Radar Jogja juga me-relaunching tim online yang diberi nama Radar Jogja Digital pada tahun 2018 guna memasifkan kinerja di platform digital dan juga tim bisnis. Sedangkan jika ditinjau dari pelaksanaannya, model konvergensi yang diterapkan di Radar Jogja adalah dengan 
mengumpulkan berita yang didapat, baik dari wartawan cetak dan tim online ke dalam satu ruang berita atau lebih dikenal dengan model konvergensi newsroom.

"Untuk kebijakan berkonvergensi itu sepenuhnya diserahkkan kepada masing-masing Radar, tetapi pihak Jawapos juga memberikan guideline secara garis besar terkait konvergensi ini. Untuk model kita lebih ke newsroom, tapi konvergensi kita belum se-serius seperti media online lainnya yang selalu update setiap saat. Jika dilihat kinerja dari tim online belum maksimal karena news yang diproduksi masih sebatas kerjasama dengan instansi-instansi yang kebanyakan sifatnya news advetorial." (Amin Surachmad, Dewan Redaksi, wawancara di kantor Radar Jogja, 6 Agustus 2019).

Konsep dari model konvergensi newsroom adalah mengumpulkan naskah berita yang dibuat oleh jurnalis yang berbeda platform ke dalam satu ruang produksi. Dalam hal ini produksi berita di Radar Jogja, baik naskah berita cetak dan materi dari tim Radar Jogja Digital dijadikan dalam satu ruang berita (single newsroom). Hal ini bermaksud untuk memudahkan editor online untuk menyunting naskah sebelum ditayangkan di website. Sedangkan untuk alur kerja surat kabar harian Radar Jogja, diawali dengan rapat redaksi yang dilakukan tiap sore hari yang bertujuan untuk merencanakan konten yang akan diterbitkan.

Wartawan wajib mengumpulkan minimal 3 naskah berita sesuai deadline yang telah ditentukan, untuk kemudian di review kembali oleh redaktur sebelum diserahkan kepada layouter. Para wartawan ini diharuskan mengirirmkan naskah maksimal pukul 16.00 WIB atau sesuai dengan deadline yang telah disepakati. Di Radar Jogja sendiri terdapat kurang lebih 14 wartawan serta 4 anggota dari Radar Jogja Digtal yang bertugas untuk meliput berita untuk koran Radar Jogja dan Radar Jogja Online. Berita yang diperoleh oleh para wartawan ini nantinya akan dikumpulkan pada satu ruang berita atau yang disebut sebagai newsroom untuk memudahkan proses produksi selanjutnya.

Namun dalam pelaksanaannya, Radar Jogja juga mengadopsi model konvergensi newsgathering, yang mana konsep dari model ini adalah jurnalis dituntut untuk mencapai tingkatan multitasking. Meski sudah terdapat pembagian jobdesk, nyatanya untuk kejadian tertentu, para wartawan dituntut untuk dapat melakukan pekerjaan untuk beberapa platform sekaligus. Hal ini dilakukan karena kendala SDM yang kurang. Oleh karena itu, selain bekerja membuat naskah berita, para wartawan juga dituntut untuk mampu meliput berita dalam bentuk video untuk mengantisipasi apabila tidak tercover oleh videografer.

"Keinginan pimpinan sebenarnya seperti itu, jurnalis kita dituntut untuk multitasking, tapi saya beranggapan kalau jurnalis cetak ya fokuslah pada kualitas naskah berita, karena dulu pernah ada wartawan yang jobdesk nya merangkap sebagai videografer, dan setelah di evaluasi, ternyata hasilnya jeblok. Kalau untuk sekarang masih (meliput video) tapi untuk kondisi yang urgen". (Yogi Istiaji Puji, Pemimpin Redaksi, wawancara di kantor Radar Jogja, 19 Agustus 2019). 
Yogi mengakui dengan bekerja untuk beberapa platfom, menjadikan kualitas berita yang dihasilkan kurang maksimal karena dirasa dapat memecah konsentrasi jurnalis. Selain itu, persoalan waktu juga menjadi kendala dalam menjalankan tugas kedua platform sekaligus. Meski demikian di sisi lain model konvergensi yang menuntut tingkatan multitasking dari jurnalis ini, membuat media tersebut mengimbangi laju perkembangan informasi yang cepat dan update. Untuk saat ini, pelaksanaan dari model konvergensi ini berjalan untuk berita yang urgent dan apabila tidak bisa ter-cover oleh tim online. Biasanya, berita urgent seperti ini akan dimuat di media sosial sebagai breaking news, sembari menunggu liputan yang lengkap yang akan dimuat di koran.

Selain itu, berdasarkan hasil observasi peneliti menemukan bahwasannya Radar Jogja juga menerapkan model konvergensi Content. Model konvergensi content adalah konvergensi yang menyajikan konten yang variatif. Output yang disuguhkan dalam bentuk multimedia, yang merupakan kombinasi antara teks, gambar, audio, video, blog, podcast atau slide show. Penerapan model konvergensi ini terlihat pada proses produksi konten dari Radar Jogja yang dikemas di berbagai jenis dan disebar ke berbagai platform. Hal ini dapat dilihat dari platform online yang terdapat kombinasi teks, video, audio dan foto. Sedangkan platform cetak, yang memiliki kombinasi konten teks, foto, infografik dan karikatur. Hal tersebut menunjukkan bahwa Radar Jogja mampu mengemas konten ke berbagai platform baik cetak, maupun online.

"Kenapa sih kita mulai masuk ke podcast ya karena kita menganggap podcast ini adalah aset gitu karena tren media saat ini kan audio visual yang itu ada di youtube nah, kita melihat tren selanjutnya itu kembali ke audio, jadi kita mulai mempersiapkan nya sejak dini. Kita melihat podcast ini nantinya akan menjadi the next youtube lah istilahnya" (Reren Indranila, Online Manager, wawancara di Kantor Radar Jogja, 2 September 2019).

Adanya tren media inilah yang melatarbelakangi Radar Jogja Digital memutuskan untuk memperluas pasar dengan membuat akun podcast meski konten nya masih terbatas.

\section{Konvergensi Kontinum Radar Jogja}

\section{Cross Promotion}

Salah satu tahapan dalam penerapan konvergensi media sebuah perusahaan dapat dilihat dari tingkat kerjasama di antara dua media untuk saling memberikan ruang guna memperkenalkan konten media satu sama lain. Biasanya hal ini dilakukan oleh media yang berada pada satu kepemilikan. Begitu pula yang dilakukan oleh Radar Jogja dalam mengenalkan medianya ke khalayak. Bentuk cross promotion atau promosi silang ini diterapkan dalam lingkup intern Radar Jogja, serta berjalan melalui platform cetak dan online. 
Academic Journal of Da'wa and Communication, Vol. 01, No. 01, April 2020

“Dalam lingkup internal kita memang melakukan cross promotion, ini dilakukan sebagai bentuk eksistensi kita sebagai media untuk bersaing dengan media massa lainnya dan juga memperluas jaringan pasar, karena kita memberikan pilihan advetorial yang beragam" (Amin Surachmad, Dewan Redaksi, wawancara di Kantor Radar Jogja, 6 Agustus 2019).

Tujuan dari adanya cross promotion ini adalah untuk memperluas jaringan pasar, sehingga diharapkan dapat meningkatkan potensi kerjasama dengan berbagai instansi atau perusahaan. Cross promotion atau promosi silang di SKH Radar Jogja biasanya disampaikan dengan menampilkan elemen visual dari platform online. Adapun bentuknya bisa dengan menampilkan logo Radar Jogja Digital maupun mencantumkan website dan sejumlah media sosial yang dikelola oleh Radar Jogja Digital.

Meski demikian, upaya cross promotion Radar Jogja masif dilaksanakan pada media sosial. Adapun bentuk dari cross promotion ini dilakukan dengan cara optimalisasi new media. Cara ini dianggap efektif mengingat pangsa pasar saat ini adalah kaum milenial yang lekat dengan teknologi informasi. Sehingga para pelaku bisnis memerlukan media untuk dapat mengenalkan produknya kepada khalayak. Di sinilah peran penting dari media massa yang berperan dalam menyebarkan informasi seluas-luasnya kepada khalayak. Semakin banyak jaringan yang dibangun maka semakin besar pula kesempatan untuk menjalin kerjasama dengan perusahaan atau instansi-instansi di bidang news advetorial.

Hal inilah yang tengah diupayakan oleh Radar Jogja untuk memberikan pelayanan ke klien dengan memberikan pilihan advetorial yang beragam. Optimalisasi penggunaan new media ini dijadikan sebagai strategi dan dijalankan pada website, akun media sosial, dan Youtube Radar Jogja. Hal yang dilakukan oleh tim Radar Jogja Digital dalam mengelola platform digitalnya dengan aktif memposting informasi atau berita yang sebelumnya telah dimuat di cetak.

\section{Cloning}

Tahapan ini memungkinkan sebuah konten media diperbanyak (cloning) untuk dimuat di media lainnya. Hal ini biasanya dilakukan oleh beberapa media nasional dengan memperoleh berita internasional melalui cloning dari agen berita internasional seperti Reuters, AP, atau Bloomberg. Adapun Radar Jogja tidak memperoleh beritanya dengan membeli berita dari agen berita melainkan dengan melansir berita tersebut dari Jawa Pos dan grup Radar. Hal ini sebagaimana yang disampaikan Dewan Redaktur Radar Jogja 
"Kita tidak beli berita dari situ mbak, kalau kita butuh berita nasional kita bisa ambil lewat Jawa Pos Newsroom. Toh kita media lokal, jadi isu-isu yang kita angkat ya seputar lokal saja. Kalaupun ada berita nasional yang sedang in ya kita buat berita dengan isu yang sama tapi di lokalisasi." Amin Surachmad Dewan Redaktur (6 Agustus 2019).

Dari kutipan diatas menjelaskan sebagai media lokal, Radar Jogja berupaya untuk menyajikan konten yang berkaitan dengan isu nasional namun dikemas sedemikian rupa dengan kearifan lokal. Hal inilah yang ingin ditunjukkan sebagai media yang memiliki diferensiasi dengan media lokal lainnya. Pemilihan isu juga menjadi salah satu hal yang tengah diperhatikan oleh Radar Jogja guna menjaga dan meningkatkan kualitasnya.

Salah satu isu yang diangkat adalah terkait pemberitaan pemadaman aliran listrik di ibukota beberapa waktu lalu. Radar Jogja mencoba menarik benang merah dari adanya pemberitaan tersebut dan dihubungkan dengan keadaan di Yogyakarta. Konten berita yang dilansir biasanya berkaitan dengan tema lifestyle dan entertainment yang nantinya akan di upload di website Radar Jogja. Alasan Radar Jogja melansir berita dari Jawa Pos untuk memenuhi kuota beritannya dikarenakan kurangnya SDM atau wartawan yang bertugas untuk meliput kedua tema tersebut. Dalam melansir berita, Radar Jogja tidak serta merta mempublikasi berita secara utuh tanpa perubahan melainkan mengambil satu subtema dalam sebuah berita lalu mengolahnya sebelum dipublikasikan.

\section{Coopetition}

Coopetition yaitu tahap ketka entitas media yang terkonvergensi saling bekerjasama dan berkompetisi di saat yang bersamaan atau kolaborasi. Hal ini biasanya terjadi pada media dalam satu kepemilikan namun masing-masing memiliki susunan redaksi dan newsroom sendiri. Berdasarkan hasil penelitian, Radar Jogja memiliki 2 platform yakni cetak berupa surat kabar harian Radar Jogja dan platform online yang disebut Radar Jogja Digital. Meski berada pada satu kepemilikan dan satu newsroom, kedua platform ini memiliki susunan redaksi serta pengelolaan keuangan sendiri. Namun, hal tersebut tidak menutup adanya kerjasama di antara kedua platform. Di samping memproduksi konten originalnya, kedua platform ini juga bekerjasama dalam hal produksi berita dan kegiatan promosional.

Dalam bidang periklanan pun kedua platform ini saling berkolaborasi dengan menyuguhkan konsep bandling advertising. Konsep ini merupakan layanan periklanan yang memberikan pilihan kepada para klien dalam memasarkan produknya.

"Untuk iklan itu tergantung kerjasama dengan pihak pengiklan. Jadi kalau si pengiklan inginnya di online ya kita buat di online. tapi dari AE (account executive) kita dalam mencari iklan itu bentuknya bandling. Misalnya iklan tentang profil desa bisa dibuat menjadi 2 
platform misal pertangung jawaban dana desa itu kan yang memungkinkan di cetak. Sedangkan kalau ingin dibuat lebih menarik dan milenial nanti jatuhnya dikemas dalam bentuk video yang dishare di platform online. Jadi nanti tergantung pengiklannya mengajukan MoU nya dengan platform mana gitu. (Reren Indranila Online Manager, wawancara dikantor Radar Jogja, Senin 2 September 2019)"

Marketing Radar Jogja biasanya memberikan penawaran terkait penempatan iklan melalui kesepakatan MoU. Umumnya, para klien akan memilih iklan dengan sistem bandling yang akan menampilkan iklannya untuk kedua platform baik cetak maupun secara online. Pengemasan iklan pun disesuaikan dengan karakter dari masing-masing platform. Untuk konten cetak, biasanya akan dibuat sebuah artikel advetorial yang akan dimuat. Sedangkan untuk konten online biasanya disajikan dalam bentuk video yang nantinya akan di distribusikan ke Youtube dan akun media sosial Radar Jogja. Dengan adanya kolaborasi ini, jumlah pengiklan untuk kedua platform meningkat.

\section{Content Sharing}

Tahapan ini, kedua platform yang berlainan (cetak dan online) saling berbagi konten dalam bentuk pengemasan ulang (repackaged) atau bahkan termasuk berbagi budgeting. Berdasarkan temuan peneliti, konten media cetak Radar Jogja mayoritas dipasok dari hasil liputan para wartawan. Sedangkan Radar Jogja Digital men-supply kontenkontennya dengan me-repackaged konten dari media cetak dan membuat konten sendiri, mengingat terdapat divisi produksi dalam tim ini.

Proses content sharing yang terlihat di Radar Jogja dibentuk melalui pertemuan antar tim yang tujuannya membahas isu atau tema apa yang kira-kira akan dimuat sepekan ke depan. Kemudian dari pertemuan tersebut menghasilkan satu keputusan untuk berbagi konten pada suatu tema yang telah disepakati. Salah satu contohnya pada peliputan berita olahraga sepakbola, masing-masing platform akan mengirimkan satu wartawan mereka untuk datang meliput. Hal ini dilakukan untuk memenuhi konten platform digital dan cetak. Dengan adanya content sharing ini memungkinkan kedua platform mendapat konten dari perspektif yang berbeda. Platform digital akan berfokus pada pembuatan konten video sedangkan platform cetak pada naskah berita.

\section{Full Convergence}

Tahapan full convergence yaitu ketika media yang berbeda bekerjasama secara penuh, baik dalam hal penumpulan, produksi, dan distribusi konten yang bertujuan untuk memaksimalkan keunikan karakteristik masing-masing media untuk menyampaikan konten. Proses konvergensi dapat dikatakan full convergence apabila memenuhi beberapa indikasi. Di antaranya ketika sebuah industri melakukan sinergi, koordinasi dan sinkronisasi antar platform yang berbeda dalam satu kepemilikan. 
Academic Journal of Da'wa and Communication, Vol. 01, No. 01, April 2020

Sehingga apa yang dihasilkan dari pola kerjasama tersebut adalah konvergensi utuh (full convergence).

Jika ditelisik kembali, Radar Jogja dan Radar Jogja Digital merupakan anak perusahaan dari Jawa Pos Grup. Meski Jawa Pos memberikan kebebasan dalam manajemen dan operasional anak perusahaannya, sebagai stakeholder, Jawa Pos juga turut andil dalam kebijakan konvergensi media ini. Sebagai leader Jawa Pos dituntut untuk menjadi contoh bagi anak perusahaannya.

Oleh karena itu kebijakan konvergensi media menjadi salah satu transformasi yang diterapkan dalam rangka mengimbangi perkembangan teknologi dengan melakukan adaptasi dan mengedepankan karya inovatif dan kreatif. Hal serupa tampaknya juga diturunkan ke anak perusahaan Jawa Pos tidak terkecuali Radar Jogja. Mengingat persaingan antar media semakin meningkat membuat Radar Jogja mencari strategi untuk bersaing dengan menerapkan konvergensi media.

Dalam hal ini, indikasi seperti sinergi, koordinasi dan sinkronisasi antar platform sudah terjalin. Hal ini dibuktikan dengan digelarnya rapat rutin kedua platform tiap minggunya.

"Untuk koordinasi antar platform kita biasanya ada rapat manajemen. Jadi masing-masing redaksi memiliki jadwal rapat sendiri dan biasanya kita mengadakan rapat manajemen setiap hari Senin. Pembahasannya ya seputar produk unggulan dari masiang-masing platform dan pembahasan mengenai strategi pengadaaan kerjasama iklan. Kita juga mengadakan rapat dengan para petinggi-petinggi Radar di seluruh Indonesia tiap tahunnya, ya tujuannya untuk saling tukar pikiran terkait kerjaan"(Amin Surachmad, Dewan Redaksi, wawancara di Kantor Radar Jogja, 6 Agustus 2019).

Meski demikian, tahapan ini belum terlaksana secara sempurna karena dalam proses produksi berita di setiap platform, Radar Jogja belum memiliki SDM wartawan yang cukup untuk memproduksi konten secara terpisah. Melihat konteks sebagai media lokal sekaligus anak perusahaan dari media ternama, konvergensi media yang dilakukan Radar Jogja bisa dikatakan sebagai konvergensi media kontekstual dalam artian konvergensi ini berlangsung dalam skala kecil karena berada di lingkup lokal dan disesuaikan dengan budaya, situasi kondisi, dan kebutuhan.

\section{Konvergensi Radar Jogja dalam Menghadapi Persaingan Media Massa}

Berdasarkan hasil analisis di atas, didapati bahwa Radar Jogja melakukan konvergensi media atas dasar beberapa hal. Pertama, adanya wacana tumbangnya sejumlah media cetak akibat gempuran media online yang mengakibatkan turunnya pembaca yang berdampak pada penurunan oplah. Selanjutnya, persaingan antar media massa juga menjadi pemicu 
Academic Journal of Da'wa and Communication, Vol. 01, No. 01, April 2020

Radar Jogja melakukan konvergensi media. Hal ini ditunjukkan dengan makin berkembangnya media massa lokal dengan merambah ke berbagai platform maupun peningkatan mutu konten. Hal tersebut membuktikan bahwa persaingan dengan sejumlah media cetak tersebut berjalan makin kompleks.

Grindle (1980) dalam Ramadani (2019) memberikan pandangan tentang implementasi dengan mengatakan bahwa secara umum, tugas implementasi adalah membentuk suatu ikatan (linkage) yang memudahkan tujuan-tujuan kebijakan bisa direalisasikan sebagai dampak dari suatu kegiatan pemerintah. Adapun implementasi konvergensi media dapat diartikan dengan suatu proses penerapan dan pengaplikasian dari adanya kebijakan konvergensi media.

Adapun implementasi konvergensi Radar Jogja dapat diketahui dengan mengidentifikasi proses produksi dan distribusi konten. Radar Jogja berkonvergensi dengan mengelola kedua platform yang mereka miliki, yakni platform cetak berupa SKH Radar Jogja dan platform online yang disebut Radar Jogja Digital. Adapun konten berita dari kedua platform tersebut diperoleh dari wartawan yang sama. Artinya, wartawan harus bersikap multitasking untuk memproduksi berita untuk kedua platform. Hal ini karena belum ada pembagian wartawan untuk kedua platform. Meski demikian, Radar Jogja Digital juga memiliki tim produksi yang berjumlah 4 orang untuk meliput konten-konten tertentu yang akan dimuat di platform mereka. Konten ini biasanya sifatnya lebih ringan seperti lifestyle, review. Konten yang diliput oleh para wartawan ini dijadikan dalam satu ruang berita yang nantinya memudahkan editor tiap platform untuk mengolah kembali sebelum dimuat masing-masing platform.

Sedangkan dalam proses distribusi konten, Radar Jogja kini telah memiliki sejumlah platform guna mendistribusikan kontennya. Adapun platform yang di kelola oleh Radar Jogja adalah surat kabar harian, website, media sosial, Youtube dan podcast. Masing-masing platform tersebut dikelola oleh 2 tim. Saat ini, tim Radar Jogja Digital tengah berupaya untuk mengembangkan platform online mengingat sasaran target mereka adalah kaum milenial yang melek teknologi. Hadirnya platform onine ini didasari karena adanya internet yang dianggap sebagai media baru (new media). Sedangkan upaya yang dilakukan oleh tim redaksi cetak guna memaksimalkan platform cetak adalah dengan terus menggali isu-isu yang sekiranya viral dan sesuai dengan target dari pembaca yakni kalangan menengah ke atas. 
Academic Journal of Da'wa and Communication, Vol. 01, No. 01, April 2020

\section{KESIMPULAN DAN SARAN}

\section{Kesimpulan}

Berdasarkan data yang telah dihimpun dan dianalisa dapat disimpulkan bahwa Radar Jogja menerapkan konvergensi media sebagai strategi bisnis yang dilakukan dalam menghadapi persaingan media massa yang berkembang secara dinamis dengan merebut pasaran di tengah masyarakat. Terbagi menjadi dua platform yaitu platform cetak dan platform digital, Radar Jogja mengadopsi ketiga model konvergensi yakni newsroom, newsgathering dan content. Adapun implementasi konvergensi media Radar Jogja dapat diketahui dengan melihat tingkat partisipasi konvergensi media tersebut.

Berdasarkan lima aspek yang diteliti meliputi cross promotion, cloning, coopetition, content sharing dan full convergence, diketahui bahwa Radar Jogja menerapkan kegiatan seperti optimalisasi new media guna mengenalkan berbagai platform dari suatu media dengan tujuan utamanya menambah jumlah viewers. Kemudian pentingnya pemilihan isu yang akan diliput juga menjadi perhatian tim Radar Jogja untuk menjaga dan meningkatkan kualitas konten. Selanjutnya yakni kerjasama antar platform di bidang advetorial, hal ini dimaksudkan untuk memberikan pilihan layanan advetorial yang beragam kepada para klien dengan sistem bandling advertising. Selain itu, membangun koordinasi yang baik antar platform juga tak luput menjadi perhatian dari manajerial Radar Jogja untuk bersinergi satu sama lain dengan tujuan meningkatkan loyalitas kepada perusahaan.

\section{Saran}

Penelitian tentang konvergensi sejatinya adalah wilayah penelitian yang luas. Masih terbuka lebar peluang untuk riset-riset selanjutnya. Mengingat jurnalisme dan new media adalah ranah kajian yang sangat dinamis dan terus berkembang dari masa ke masa. Riset ini juga masih sebatas satu media, sementara di Indonesia ada banyak sekali media yang dapat dijadikan objek penelitian.

\section{DAFTAR PUSTAKA}

APL. (2017). "Satu Lagi Media Cetak Tutup Usia" diakses pada 4 Oktober 2019 dari https://www.jawapos.com/jpg-today/31/12/2017/satu-lagi-media-cetak-tutupusia/

Bawapratama, C. R. (2010). Konvergensi Media dan Perubahan dalam Manajemen SDM Media. Jurnal Komunikasi, 5, 7-22.

Dailey, L., Demo, L., \& Spillman, M. (2003). The Convergence Continuum: A Model for Studying Collaboration Between Media Newsrooms. Association for Education in Journalism and Mass Communication, 1-28.

Fadilah, E. (2017). Podcast sebagai Alternatif Distribusi Konten Audio. Jurnal Kajian Jurnalisme, 1, 90-104.

Gumelar, R.G. (2013). Konvergensi Media Online. Jurnal Komunikasi, 2, 6-14.

Haryati. (2012). Ekologi Media di Era Konvergensi. Jurnal Observasi, 10, 147-168. 
Irawan, R. E. (2014). Aplikasi Citizen Journalism di Era Konvergensi Media. Jurnal Humaniora, 2, 816-821.

Jenkins, H. (2006). Convergence Culture, Where Old and New Media Collide. New York University.

Manan, A. (2018). Ancaman Baru Dari Digital Laporan Tahunan AJI 2018. Jakarta: Aliansi Jurnalis Independen (AJI).

Moleong, L. J. (2007). Metodologi Penelitian Kualitatif. Bandung: Remaja Rosda Karya.

Nasrullah, R. (2014). Teori dan Riset Media Siber (Cybermedia). Jakarta: Kencana Prenamedia.

Nastiti, A. D. (2012). Membangun Pasar Media Lokal melalui Konvergensi Media (Studi Penerapan Konvergensi Media pada Jaringan Koran Tribun). Universitas Indonesia.

Nielsen. (2017). “Tren Baru Di Kalangan Pengguna Internet Di Indonesia” diakses pada 4 Oktober 2019 dari https://www.nielsen.com/id/en/press-releases/2017/trenbaru-di-kalangan-pengguna-internet-di-indonesia/

Nielsen. (2017). "Tren Baru di Kalangan Pengguna Internet di Indonesia" diakses pada 4 Oktober 2019 dari https:www.nielsen.com/id/en/press-release/2017/tren-barudi-kalangan-pengguna-internet-di-indonesia/

Nurliah. (2018). Konvergensi dan Kompetisi Media Massa dalam Memenangkan Pasar di Era Media Digital di Makassar. Jurnal Tabligh, 19, 106-118.

Pasallo, F. A. S. (2013). Peran Media Massa Cetak (Koran) dalam Meningkatkan Pariwisata Danau Dua Rasa (Labuan Cermin), Berau. eJurnal Ilmu Komunikasi, 1,91-105.

Permana, F.Y. (2017). Mempertahankan Pasar Media Cetak Melalui Konten Augmented Reality/AR (Studi Pada Koran Tribun Jogja). Jurnal Channel, 5, 77-90.

Prihartono, A.W. (2016). Surat Kabar \& Konvergensi Media (Studi Deskriptif Kualitatif Model Konvergensi Media Pada Solopos). Jurnal Channel, 4, 105-116.

Ramadani, T. (2019). Implementasi Kebijakan Pengelolaan Komunikasi Publik di Kementrian Energi dan Sumber Daya Mineral. Jurnal Borneo Administrator,12, 1-18.

Rizky, A. P. (2018). "Menakar Umur Media Cetak Indonesia" diakses pada 4 Oktober 2019 https://www.alinea.id/media/menakar-umur-media-cetak-indonesia-b1Uuz98E.

Romadhoni, B.A. (2018). Meredupnya Media Cetak, Dampak Kemajuan Teknologi Informasi. Jurnal An-Nida, 10, 13-20.

Santhika, E. (2018). “Rolling Stone Indonesia Tutup" diakses pada tanggal 4 Oktober 2019 dari https:// www.cnnindonesia.com/hiburan/20180101101330-227265850/rolling-stone-indonesia-tutup.

Sugiya, A. (2012). Strategi Transformasi Konvergensi Media (Studi Kasus Grand Strategy Harian Kompas). Tesis Magister Sains, Universitas Indonesia.

Syafina, D. C. (2018). "Tabloid Bola Tutup dan Sandaran Baru Bisnis Kompas Gramedia Group" diakses pada tanggal 4 Oktober 2019 dari https://tirto.id/tabloid-bolatutup-dan-sandaran-baru-bisnis-kompas-gramedia-group-c7GE.

Trinoviana, A. (2017). Strategi Konvergensi Radio Sebagai Upaya Perluasan Pasar Audience dan Iklan. Jurnal Komunikasi, 12, 35-49.

Trijayanto, D. (2015). Implikasi Konvergensi Media Terhadap Industri “Premateur Industri Penyiaran Televisi Digital Pada Teknologi Layanan Mobile Television di Indonesia". Jurnal Promedia, 1, 19-45. 